\title{
Who seeks public treatment for substance abuse in Brazil? Results of a multicenter study involving four Brazilian state capitals
}

\author{
Quem procura tratamento para abuso de substância na rede pública no Brasil? \\ Resultados de um estudo multicêntrico envolvendo quatro capitais brasileiras
}

\author{
Sibele Faller, ${ }^{1}$ Ana Carolina Peuker, ${ }^{1}$ Anne Sordi, ${ }^{1}$ Anderson Stolf, ${ }^{1}$ Maria Lucia Souza-Formigoni, ${ }^{2}$ \\ Marcelo Santos Cruz, ${ }^{3}$ Sílvia Brasiliano, ${ }^{4}$ Flavio Pechansky, ${ }^{1}$ Felix Kessler ${ }^{1}$
}

\begin{abstract}
Objective: To assess the characteristics of alcohol and drug users who seek treatment at the Brazilian Unified Health System in Brazil.

Method: A multicenter cross-sectional study involving five clinical and research centers located in four Brazilian state capitals was conducted with 740 in- and outpatients. The only exclusion criterion was the presence of neurological or severe psychiatric symptoms at the moment of the interview. The Addiction Severity Index (ASI-6) and the Alcohol, Smoking and Substance Involvement Screening Test (ASSIST) were used to assess the severity of substance use and the problems related.

Results: There were significantly more men than women in the sample; mean age was 36 years. The drug most frequently used at all sites was alcohol (78\%), followed by cocaine/crack (51\%). Alcohol was the drug that most commonly motivated treatment seeking, at all centers. ASI-6 Summary Scores for Recent Functioning (SS-Rs) were quite similar among centers. SS-Rs were compared between users who had never received treatment for psychoactive substance abuse $(n=265,36.1 \%)$ and those who had already been treated at one or more occasions ( $n=470$, $63.9 \%$ ). This analysis revealed significant differences between the groups in the drug, psychiatric symptoms, legal, and family/ social problems areas $(p<0.05)$.

Conclusion: Our findings confirm previous evidence suggesting that the management of patients seeking drug abuse treatment should take several different aspects into consideration, e.g., education, employment, and family relationships, which often appear as areas of concern for these individuals.

Keywords: Substance abuse, treatment, multicenter, alcohol, drugs, public health.
\end{abstract}

\section{Resumo}

Objetivo: Avaliar as características dos usuários de álcool e drogas que procuram tratamento no Sistema Único de Saúde.

Método: Estudo transversal multicêntrico envolvendo cinco centros clínicos/de pesquisa localizados em quatro capitais brasileiras foi realizado com 740 pacientes hospitalizados e ambulatoriais. O único critério de exclusão foi a presença de sintomas neurológicos ou psiquiátricos graves no momento da entrevista. A Escala de Gravidade de Dependência (Addiction Severity Index, ASI-6) e o teste ASSIST (Alcohol, Smoking and Substance Involvement Screening Test) foram utilizados para avaliar a severidade do uso de substância e problemas relacionados.

Resultados: Houve significativamente mais homens do que muIheres na amostra; a idade média foi de 36 anos. A droga mais usada em todos os centros foi o álcool (78\%), seguido de cocaína/ crack ( $51 \%)$. O álcool foi a droga que mais motivou procura por tratamento, em todos os centros. Os Escores Resumidos da ASI-6 para Funcionamento Recente (SS-Rs) foram bastante similares nos centros. SS-Rs foram comparados entre usuários que nunca haviam recebido tratamento para abuso de substâncias ( $n=265$, $36,1 \%$ ) e aqueles que já haviam sido tratados uma ou mais vezes ( $n=470,63,9 \%)$. Foram observadas diferenças significativas entre os grupos nas áreas de droga, sintomas psiquiátricos e problemas legais e familiares/sociais $(p<0,05)$.

Conclusões: Nossos dados confirmam evidências prévias de que o manejo de pacientes que procuram tratamento para abuso de substância deve levar em conta vários aspectos, como educação, emprego e relações familiares, que normalmente geram preocupação nesses indivíduos.

Descritores: Abuso de substâncias, tratamento, multicêntrico, álcool, drogas, saúde pública.

\footnotetext{
${ }^{1}$ Center for Drug and Alcohol Research, Universidade Federal do Rio Grande do Sul (UFRGS), Porto Alegre, RS, Brazil. ${ }^{2}$ Department of Psychobiology, Universidade Federal de São Paulo (UNIFESP), São Paulo, SP, Brazil. ${ }^{3}$ Institute of Psychiatry, Universidade Federal do Rio de Janeiro (UFRJ), Rio de Janeiro, RJ, Brazil. ${ }^{4}$ Women Drug Dependent Treatment Center, Universidade de São Paulo (USP), São Paulo, SP, Brazil.

Financial support: Secretaria Nacional de Políticas sobre Drogas (SENAD).

Submitted Sep 16 2014, accepted for publication Nov 06 2014. No conflicts of interest declared concerning the publication of this article.

Suggested citation: Faller S, Peuker AC, Sordi A, Stolf A, Souza-Formigoni ML, Cruz MS, et al. Who seeks public treatment for substance abuse in Brazil? Results of a multicenter study involving four Brazilian state capitals. Trends Psychiatry Psychother. 2014;36(4):193-202. http://dx.doi.org/10.1590/2237-6089-2014-0040
} 


\section{Introduction}

Psychoactive drug consumption has become a serious problem in developing countries. In Brazil, the largest country in Latin America, reported prevalence rates of alcohol and drug abuse vary across studies, but one common finding is the high lifetime prevalence of use of any drug or alcohol, reaching 22.8 and $74.6 \%$, respectively. ${ }^{1}$ In the last decade, epidemiological studies conducted in Brazil have reported an increase in lifetime consumption of alcohol, tobacco, marijuana, inhalants, cocaine, and other drugs. ${ }^{1,2}$ Such a scenario has implications not only for the individual user, in terms of psychological and social problems, but also for the society at large, in terms of the significant economic impact associated with drug abuse. ${ }^{3}$

In response to the increased prevalence of psychoactive drug abuse, there is a growing interest in variables that may influence treatment effectiveness. ${ }^{4-7}$ For example, active participation in treatment has been associated with positive outcomes among psychoactive drug users. ${ }^{8}$ However, many drug users do not even start treatment, many leave treatment prematurely, or yet relapse following treatment completion. ${ }^{5}$ In this context, several authors have focused on addictive behaviors and tried to better understand the factors that motivate individuals to seek treatment for substance abuse, ${ }^{5}$ as well as barriers to treatment-seeking ${ }^{7}$ and outcome predictors. ${ }^{4}$

In spite of many scientific efforts, a number of questions still remain unclear, especially regarding access to treatment, treatment compliance, and treatment effectiveness. In Brazil, some studies have assessed drug abuse characteristics in the general population, however only a few have involved clinical samples. ${ }^{2,9}$ Among the limitations commonly mentioned by Brazilian investigators, political and logistical issues stand out, including limited funding and staff, which result in small or nonrepresentative samples and directly affect the quality of research. According to some authors, this scenario can be explained by the recent history of drug use research in developing nations. ${ }^{10}$ Finally, research conducted in large countries, such as Brazil, have the additional limitation of dealing with cultural and social differences as a result of data collection at different sites.

Having an improved knowledge of the profile of patients seeking treatment for substance abuse is extremely important to ensure adequate treatment planning. For instance, many treatment seekers have psychiatric comorbidities, use multiple drugs concurrently, or present deficits in several areas of their lives. An English study that evaluated the profile of treatment-seeking drug users found a higher prevalence of psychiatric disorders among multiple drug users, and also revealed that female gender, physical health, interpersonal relationships, and drug dependence are important predictors of psychiatric symptoms. ${ }^{11}$

Currently, drug abuse treatment in Brazil is available to the population free of charge via the National Unified Health System. Treatment is offered at psychosocial care centers specialized in alcohol and drug abuse, private clinics, and specialized hospitals. Patients are referred to these different levels of care according to abuse severity. ${ }^{12,13}$ In addition, nationwide preventive and treatment programs are often implemented by the government. Still, very little is known about the profile of patients that seek and benefit from these initiatives, about their reasons motivating treatment seeking, and about the severity of problems related to drug abuse in different Brazilian regions.

Therefore, the objectives of the present study were to assess the characteristics of alcohol and drugs users who seek treatment at the Brazilian Unified Health System in four Brazilian states, with a focus on addiction severity and the drug that motivated treatment seeking.

\section{Methods}

This was a multicenter cross-sectional study involving five research centers located in four Brazilian state capitals.

\section{Data collection sites}

The data collection sites were strategically chosen due to their previously reported ability to conduct large studies in the field and are described below:

- The Center for Drug and Alcohol Research (Centro de Pesquisa em Álcool e Drogas, CPAD), at the Universidade Federal do Rio Grande do Sul (UFRGS), was the coordinating center for this study.

- The Drug Dependence Unit (Unidade de Dependência de Drogas, UDED), a section of the Department of Psychobiology of the Universidade Federal de São Paulo (UNIFESP).

-The Women's Drug Dependent Treatment Center (Programa de Atenção à Mulher Dependente Química, PROMUD), affiliated with the Medical School of Universidade de São Paulo (USP). Provides treatment mostly for women.

- The Research and Assistance Program in Drug Addiction (Programa de Estudos e Assistência ao Uso Indevido de Drogas, PROJAD), affiliated with the Universidade Federal do Rio de Janeiro.

- The Center for Drug Abuse Studies and Therapy (Centro de Estudos e Terapia do Abuso de Drogas, CETAD), a permanent extension of the Department of Pathology at the Universidade Federal da Bahia (UFBA). 
Referrals from other treatment locations were also analyzed by all data collection sites.

\section{Sample selection}

Between January and November 2007, a target sample of 740 subjects was obtained. Patients were either under assessment or already being treated for substance abuse or dependence on an inpatient (first 15 days after admission) or outpatient (first 10 days) basis. The goal was to interview 150 subjects at each study center.

Patients were included in the study if they had used alcohol or drugs in the 30 days preceding the interview. The only exclusion criterion was the presence of neurological or severe psychiatric illness with symptoms at the moment of the interview, ascertained by trained clinical interviewers. Regarding data collection at all centers, seven patients were not included in the sample due to severe depressive or psychotic symptoms, and four patients did not accept to participate in the study. The strategy of including patients from both inpatient and outpatient treatment regimens was intended to generate a heterogeneous sample, with characteristics of the typical Brazilian population who seeks specialized treatment for alcohol and drug abuse.

\section{Instruments}

The following instruments were used to assess patients:

- Sixth version of the Addiction Severity Index (ASI6), a multidimensional semistructured interview lasting between 45 and 90 minutes. In the present study, a validated Brazilian Portuguese version of the instrument was used. The instrument assesses the patient's lifetime and recent status in seven functional areas or subscales, namely, medical status, employment and support, legal status, family and social status, psychiatric status, alcohol use, and drug use. Presently, one set of summary scores is available, the ASI-6 Summary Scores for Recent Functioning (SS-Rs), comprised of nine subscales covering status/functioning in the past 30 days, provides objective information by combining rational and empirical methods. The SS-Rs are psychometrically derived using the nonparametric item response theory (NIRT) and classical psychometric methods; they are standardized scores and thus have the advantage of reducing the extent of skewness in scores. One score is generated for each area/subscale, except for the family/social area, in which three scores are generated (problems, support, and child problems).
The SS-Rs are standardized T-scores with a mean of 50 and a standard deviation of 10 , and may range from 0 to 100, where higher scores indicate greater severity. ${ }^{14}$

- The Alcohol, Smoking and Substance Involvement Screening Test (ASSIST), developed by a team of investigators supported by the World Health Organization to detect substance use and abuse, and validated for Brazilian Portuguese. ${ }^{15}$ The ASSIST instrument has shown high sensitivity and specificity for the detection of alcohol, cannabis and cocaine abuse/dependence, in addition to high reliability (Cronbach's alpha of 0.80 for alcohol, 0.79 for cannabis, and 0.81 for cocaine).$^{15}$

\section{Interviewers}

All the 25 interviewers involved in the study graduated psychologists. Interviewer selection was based on the candidate's abilities in multiple areas, including: a) experience in dealing with sensitive questions, such as drug use and its consequences; b) comprehension of research principles and experience in obtaining informed consent; c) interest in the objectives of the study; and d) ability to apply a structured interview.

\section{Logistics and quality control}

The quality of the data collected was ensured mostly via training, supervisory oversight, and support provided to the field interviewers (psychologists) by the research center coordinators. Throughout data collection, a weekly meeting was held with the co-PI (FK) of each data collection site to oversee the data collection process and solve logistical problems. After data collection, each site was responsible for sending the original questionnaires to the coordinating center in Porto Alegre, state of Rio Grande do Sul (CPAD/UFRGS), where all data were entered into a single database. On a weekly basis, the PI (FP) called or emailed the co-PIs to discuss patient recruitment and solve problems related to data collection.

\section{Statistical analysis}

Data were entered into an Access database and analyzed using the Statistical Package for the Social Sciences (SPSS) version 16.0. Categorical variables were described as absolute frequencies and percentages. Quantitative variables with a symmetrical distribution were described as means and standard deviation, and those with an asymmetrical distribution were presented as medians and interquartile ranges. 
Table 1 - Sample characteristics of substance abusers who sought treatment $(n=740)$

\begin{tabular}{|c|c|c|c|c|c|c|c|}
\hline & $\begin{array}{c}\text { CETAD } \\
\text { (BA) }\end{array}$ & $\begin{array}{c}\text { PROJAD } \\
\text { (RJ) }\end{array}$ & $\begin{array}{c}\text { PROMUD } \\
\text { (SP) }\end{array}$ & $\begin{array}{l}\text { UDED } \\
\text { (SP) }\end{array}$ & $\begin{array}{l}\text { CPAD } \\
\text { (RS) }\end{array}$ & $\mathbf{p}$ & TOTAL \\
\hline Male sex (\%) & $85.2^{\mathrm{a}}$ & $86.0^{\mathrm{a}}$ & $46.2^{b}$ & $88.7^{a}$ & $80.7^{a}$ & $<0.001$ & 78.0 \\
\hline Mean age \pm standard deviation & $31 \pm 12^{\mathrm{b}}$ & $37 \pm 11^{\text {ac }}$ & $40 \pm 12^{c}$ & $36 \pm 10^{c}$ & $36 \pm 12^{\mathrm{a}}$ & $<0.001$ & $36 \pm 12$ \\
\hline Income ( $R \$^{*}$ - past 6 months) & $\begin{array}{c}4,000 \\
(1,835- \\
8,400)^{\text {bd }}\end{array}$ & $\begin{array}{c}2,400 \\
(1,000- \\
5,000)^{\text {ae }}\end{array}$ & $\begin{array}{c}2,400 \\
(1,508- \\
4,900)^{\text {be }}\end{array}$ & $\begin{array}{c}5,500 \\
(2,956- \\
8,700)^{\text {cd }}\end{array}$ & $\begin{array}{c}3,000 \\
(1,237- \\
9,700)^{\text {abce }}\end{array}$ & $<0.001$ & $\begin{array}{c}3,600 \\
(1,600- \\
7,200)\end{array}$ \\
\hline Steady partner (\%) & $35.0^{\mathrm{a}}$ & $33.3^{\mathrm{ab}}$ & $20.7^{\mathrm{b}}$ & $40.0^{\mathrm{a}}$ & $40.0^{\mathrm{a}}$ & 0.002 & 34 \\
\hline White ethnicity (\%) & $20.1^{\mathrm{b}}$ & $47.3^{\mathrm{a}}$ & $59.1^{\text {ac }}$ & $72.3^{c}$ & $62^{\mathrm{ac}}$ & $<0.001$ & 52.5 \\
\hline Outpatient treatment (\%) & $46.3^{\mathrm{de}}$ & $35.1^{\text {be }}$ & $97.3^{a}$ & $65.8^{c}$ & $57^{\text {acd }}$ & $<0.001$ & 60.5 \\
\hline Elementary and high school (\%) & $80.7^{a}$ & $62.7^{\mathrm{cd}}$ & $56.7^{\mathrm{bc}}$ & $77.3^{\mathrm{a}}$ & $74.7^{\mathrm{ae}}$ & $<0.001$ & 70.3 \\
\hline Unemployed (\%) & $43.3^{\mathrm{ab}}$ & $51.3^{\mathrm{a}}$ & $57.3^{\mathrm{a}}$ & $34^{b}$ & $50.7^{\mathrm{a}}$ & 0.001 & 47.4 \\
\hline
\end{tabular}

CETAD (BA) = Center for Drug Abuse Studies and Therapy (Bahia); PROJAD (RJ) = Research and Assistance Program in Drug Addiction (Rio de Janeiro); PROMUD $(\mathrm{SP})=$ Women's Drug Dependent Treatment Center (São Paulo); UDED (SP) = Drug Dependence Unit (São Paulo); CPAD (RS) = Center for Drug and Alcohol Research (Rio Grande do Sul).

$* \mathrm{R} \$=$ Reais; $\mathrm{R} \$ 2.5$ are equivalent to US\$ 1 .

Results followed by different letters indicate the presence of statistically significant differences.

\section{Ethical considerations}

All patients were submitted to standard informed consent procedures and were only allowed to sign the consent forms after a thorough review of patients' rights and of the study objectives and limitations. The study was approved by the Institutional Review Board of Hospital de Clínicas de Porto Alegre (HCPA), Brazil, and by the respective boards of all centers included in the study. Patients received the equivalent of $U \$ 15$ after each interview as a compensation for their costs with food and transportation.

\section{Results}

Table 1 shows the demographic characteristics of the sample. There were significantly more men than women in the sample; the mean age was 36 years, but users from the CETAD center were younger than those selected at other centers. This center also showed a lower prevalence of white ethnicity. Education level was significantly lower at the PROMUD center. Unemployment was higher at the UDED center, however without a significant difference when compared with the other centers.

Categorical variables are expressed as absolute frequencies and percentages. Quantitative variables with a symmetrical distribution are expressed as means and standard deviation. Variables with an asymmetrical distribution are expressed as medians and interquartile ranges. Quantitative variables were compared using analysis of variance (ANOVA), followed by Tukey's test; categorical variables were analyzed by chi-square test and multiple comparisons, and asymmetrical by Kruskal-Wallis.

The drug most frequently used at all sites was alcohol, followed by cocaine/crack. Marijuana was the third most frequent drug, and its use was more pronounced at CETAD, in the state of Bahia. Other psychoactive substances were homogeneously used across the centers, except for inhalants, which were more prevalent at PROJAD, in Rio de Janeiro (Table 2).

Table 2 - Use of alcohol and other drugs at the five research centers assessed

\begin{tabular}{|c|c|c|c|c|c|c|c|}
\hline Alcohol/drug use (prior 30 days) & $\begin{array}{c}\text { CETAD } \\
\text { (BA) }\end{array}$ & $\begin{array}{c}\text { PROJAD } \\
\text { (RJ) }\end{array}$ & $\begin{array}{c}\text { PROMUD } \\
\text { (SP) }\end{array}$ & $\begin{array}{l}\text { UDED } \\
\text { (SP) }\end{array}$ & $\begin{array}{l}\text { CPAD } \\
\text { (RS) }\end{array}$ & $\mathbf{p}$ & $\begin{array}{c}\text { All centers } \\
\mathrm{n}=740(\%)\end{array}$ \\
\hline Alcohol & $107(76.4)$ & $127(84.7)$ & $126(84.0)$ & $122(81.3)$ & $122(81.3)$ & 0.389 & $604(81.6)$ \\
\hline Marijuana & $74(52.9)^{\mathrm{a}}$ & $57(38.0)^{\mathrm{ab}}$ & $48(32.0)^{b}$ & $61(40.7)^{a b}$ & $62(41.3)^{a b}$ & 0.010 & $302(40.8)$ \\
\hline Sedatives & $42(30.0)^{b}$ & $48(32.0)^{b}$ & $47(31.3)^{\mathrm{b}}$ & $20(13.3)^{\mathrm{a}}$ & $42(28.0)^{\mathrm{b}}$ & 0.001 & $199(26.9)$ \\
\hline Cocaine/crack & $75(53.6)^{a b}$ & $87(58.0)^{\mathrm{a}}$ & $62(41.3)^{\mathrm{b}}$ & $76(50.7)^{\mathrm{ab}}$ & $78(52.0)^{\mathrm{ab}}$ & 0.026 & $378(51.1)$ \\
\hline Stimulants & $6(4.3)$ & $4(2.7)$ & $5(3.3)$ & $7(4.7)$ & $5(3.3)$ & 0.903 & $27(3.6)$ \\
\hline Hallucinogens & $9(6.4)$ & $3(2.0)$ & $2(1.3)$ & $5(3.3)$ & $4(2.7)$ & 0.132 & $23(3.1)$ \\
\hline Inhalants & $2(1.4)^{a b}$ & $18(12.0)^{\mathrm{a}}$ & $2(1.3)^{b}$ & $4(2.7)^{a b}$ & $6(4.0)^{\mathrm{ab}}$ & $<0.001$ & $32(4.3)$ \\
\hline Opiates & $1(0.7)$ & $1(0.7)$ & $1(0.7)$ & $2(1.3)$ & $0(0)$ & 0.742 & 11 (1.5) \\
\hline
\end{tabular}

Results expressed as number of subjects (\%).

CETAD (BA) = Center for Drug Abuse Studies and Therapy (Bahia); PROJAD (RJ) = Research and Assistance Program in Drug Addiction (Rio de Janeiro); PROMUD $(\mathrm{SP})=$ Women's Drug Dependent Treatment Center (São Paulo); UDED (SP) = Drug Dependence Unit (São Paulo); CPAD (RS) = Center for Drug and Alcohol Research (Rio Grande do Sul).

Results followed by different letters indicate the presence of statistically significant differences. 
Table 3 - Characteristics of alcohol use at the five research centers assessed

\begin{tabular}{|c|c|c|c|c|c|c|c|}
\hline Variables & $\begin{array}{l}\text { CETAD } \\
\text { (BA) }\end{array}$ & $\begin{array}{l}\text { PROJAD } \\
\text { (RJ) }\end{array}$ & $\begin{array}{l}\text { PROMUD } \\
\text { (SP) }\end{array}$ & $\begin{array}{l}\text { UDED } \\
\text { (SP) }\end{array}$ & $\begin{array}{l}\text { CPAD } \\
\text { (RS) }\end{array}$ & $\mathbf{p}$ & $\begin{array}{c}\text { All centers } \\
\mathrm{n}=\mathbf{7 4 0}(\%)\end{array}$ \\
\hline Years of alcohol use* & $3(0-13)^{a}$ & $11(2-20)^{b}$ & $10(3-20)^{b}$ & $5(0-16)^{\mathrm{ac}}$ & $9(0-20)^{a b c}$ & $<0.001$ & $8(0-18)$ \\
\hline Years of alcohol abuse ${ }^{+}$ & $2(0-8)^{c}$ & $9(1-18)^{b}$ & $7(1-15)^{\mathrm{ab}}$ & $4(0-15)^{\mathrm{ac}}$ & $3(0-14)^{a c}$ & $<0.001$ & $5(0-15)$ \\
\hline Alcohol use (days) ${ }^{\ddagger}$ & $8(1-15)^{a}$ & $15(3-30)^{b}$ & $10(3-23)^{a b}$ & $8(1-24)^{a b}$ & $7(1-25)^{\mathrm{ab}}$ & 0.003 & $10(1-23)$ \\
\hline Binge drinking (days) ${ }^{\ddagger}$ & $4(0-13)^{a}$ & $15(1-29)^{b}$ & $8(0-20)^{a b}$ & $3(0-19)^{a}$ & $3(0-20)^{a}$ & $<0.001$ & $5(0-20)$ \\
\hline Years of drug use* & $5(0-10)^{a}$ & $10(0-15)^{b}$ & $5(0-15)^{\mathrm{ab}}$ & $8(0-15)^{\mathrm{ab}}$ & $7(0-13)^{\mathrm{ab}}$ & 0.048 & $7(0-14)$ \\
\hline Concomitant use of drugs ${ }^{\ddagger}$ & $13(1-27)^{\mathrm{a}}$ & $8(0-26)^{\mathrm{ab}}$ & $2(0-15)^{b}$ & $7(0-28)^{a b}$ & $8(0-28)^{a b}$ & 0.006 & $7(0-25)$ \\
\hline
\end{tabular}

Results expressed as medians (interquartile ranges).

CETAD (BA) = Center for Drug Abuse Studies and Therapy (Bahia); PROJAD (RJ) = Research and Assistance Program in Drug Addiction (Rio de Janeiro); PROMUD $(\mathrm{SP})=$ Women's Drug Dependent Treatment Center (São Paulo); UDED (SP) = Drug Dependence Unit (São Paulo); CPAD (RS) = Center for Drug and Alcohol Research (Rio Grande do Sul).

* 3 times per week or more; ${ }^{+} 5$ drinks per day or more; ${ }^{*}$ in the preceding 30 days.

Results followed by different letters indicate the presence of statistically significant differences.

Table 3 describes the profile of alcohol consumption in the sample. There were significant differences in relation to years of alcohol use and abuse. CETAD, in the state of Bahia, showed the lowest time of alcohol use (in years), while PROJAD and PROMUD presented the highest results for this variable. The CPAD center also showed the lowest results for alcohol use, although differences were not significant. Alcohol use and binge drinking were higher at PROJAD and PROMUD when compared to the other centers. Drug use among alcohol users was more prevalent at CETAD.

In the analysis of SS-Rs, the family/child subscale presented higher results at the CPAD when compared with the other centers (significant differences in relation to PROJAD, PROMUD, and UDED). Also, there was a lower prevalence of legal problems at both sites located in the state of São Paulo (PROMUD and UDED).
Conversely, severity of problems related to Family/ Social Support showed a significantly lower prevalence at CETAD when compared with PROJAD, PROMUD, and UDED (Table 4).

Alcohol was the drug that most commonly motivated treatment seeking in the sample assessed, at all centers. The PROJAD center showed a higher prevalence of cocaine and a lower prevalence of crack as the drugs that motivated treatment seeking (Table 5).

A final analysis was conducted, using Student's $t$ test, to compare SS-Rs between users who had never received treatment for psychoactive substance abuse ( $n=265,36.1 \%$ of the sample) and those who had already been treated for substance abuse at one or more occasions ( $n=470,63.9 \%$ ). This analysis revealed significant differences between the two groups in the following areas: drug, psychiatric symptoms, legal, and family/social problems $(p<0.05)$.

Table 4 - Summary scores of the Addiction Severity Index (SS-Rs, ASI-6) obtained at the five research centers involved

\begin{tabular}{|c|c|c|c|c|c|c|c|}
\hline SS-R subscales & $\begin{array}{c}\text { CETAD } \\
\text { (BA) }\end{array}$ & $\begin{array}{c}\text { PROJAD } \\
\text { (RJ) }\end{array}$ & $\begin{array}{l}\text { PROMUD } \\
\text { (SP) }\end{array}$ & $\begin{array}{l}\text { UDED } \\
\text { (SP) }\end{array}$ & $\begin{array}{l}\text { CPAD } \\
\text { (RS) }\end{array}$ & $\mathbf{p}$ & $\begin{array}{c}\text { All centers } \\
\mathrm{n}=\mathbf{7 4 0}(\%)\end{array}$ \\
\hline Drug & $49.8 \pm 10.4^{a}$ & $47.4 \pm 10.8^{\mathrm{ab}}$ & $45.5 \pm 11.2^{b}$ & $47.8 \pm 12.0^{\mathrm{ab}}$ & $49.1 \pm 11.5^{\mathrm{a}}$ & 0.012 & $47.9 \pm 11.3$ \\
\hline Family/child & $52.9 \pm 8.1^{\text {ac }}$ & $51.5 \pm 7.5^{\mathrm{a}}$ & $51.2 \pm 7.1^{\mathrm{a}}$ & $49.6 \pm 5.3^{d}$ & $54.8 \pm 9.3^{\mathrm{bc}}$ & $<0.001$ & $52.0 \pm 7.7$ \\
\hline Alcohol & $53.9 \pm 10.3^{a}$ & $56.9 \pm 9.4^{\mathrm{ab}}$ & $57.3 \pm 9.8^{\mathrm{b}}$ & $55.2 \pm 11.0^{\mathrm{ab}}$ & $56.0 \pm 10.5^{\mathrm{ab}}$ & 0.033 & $55.8 \pm 10.3$ \\
\hline Psychiatric & $48.4 \pm 7.7^{a}$ & $51.2 \pm 8.4^{\mathrm{a}}$ & $50.0 \pm 8.4^{\mathrm{ab}}$ & $50.6 \pm 8.4^{\mathrm{ab}}$ & $51.5 \pm 8.7^{b}$ & 0.017 & $50.4 \pm 8.4$ \\
\hline Medical & $45.5 \pm 8.6^{\mathrm{a}}$ & $49.0 \pm 8.5^{b}$ & $45.2 \pm 10.1^{\mathrm{a}}$ & $44.3 \pm 10.6^{a}$ & $49.2 \pm 9.1^{\mathrm{b}}$ & $<0.001$ & $46.6 \pm 9.6$ \\
\hline Legal & $51.2 \pm 7.7^{a}$ & $51.8 \pm 6.9^{a}$ & $47.6 \pm 4.8^{\mathrm{b}}$ & $47.8 \pm 4.9^{b}$ & $51.0 \pm 7.3^{\mathrm{a}}$ & $<0.001$ & $49.9 \pm 6.7$ \\
\hline Employment & $40.5 \pm 11.1^{\mathrm{a}}$ & $45.9 \pm 9.3^{b}$ & $43.7 \pm 10.1^{\mathrm{a}}$ & $39.8 \pm 11.6^{\mathrm{a}}$ & $42.7 \pm 10.8^{\mathrm{ab}}$ & $<0.001$ & $42.6 \pm 10.8$ \\
\hline Family/social support & $43.2 \pm 10.2^{\mathrm{a}}$ & $47.5 \pm 10.1^{\mathrm{bc}}$ & $47.2 \pm 11^{\mathrm{bd}}$ & $47.8 \pm 10.8^{\mathrm{cd}}$ & $44.5 \pm 9.8^{\mathrm{ab}}$ & $<0.001$ & $46.1 \pm 10.5$ \\
\hline Family/social problem & $56.4 \pm 9.0^{\mathrm{a}}$ & $54.9 \pm 8.5^{\mathrm{acd}}$ & $53 \pm 10.3^{b c}$ & $52.1 \pm 8.8^{\mathrm{bd}}$ & $56.7 \pm 9.5^{a}$ & $<0.001$ & $54.7 \pm 9.3$ \\
\hline
\end{tabular}

Results expressed as mean \pm standard deviation.

CETAD (BA) = Center for Drug Abuse Studies and Therapy (Bahia); PROJAD (RJ) = Research and Assistance Program in Drug Addiction (Rio de Janeiro); PROMUD $(\mathrm{SP})=$ Women's Drug Dependent Treatment Center (São Paulo); UDED (SP) = Drug Dependence Unit (São Paulo); CPAD (RS) = Center for Drug and Alcohol Research (Rio Grande do Sul).

Results followed by different letters indicate the presence of statistically significant differences. 
Table 5 - Drugs motivating treatment seeking at the different centers assessed

\begin{tabular}{lccccccc}
\hline $\begin{array}{l}\text { First, second or third drug motivating } \\
\text { treatment seeking }\end{array}$ & $\begin{array}{c}\text { CETAD } \\
\text { (BA) }\end{array}$ & $\begin{array}{c}\text { PROJAD } \\
\text { (RJ) }\end{array}$ & $\begin{array}{c}\text { PROMUD } \\
(\text { (SP) }\end{array}$ & $\begin{array}{c}\text { UDED } \\
\text { (SP) }\end{array}$ & $\begin{array}{c}\text { CPAD } \\
\text { (RS) }\end{array}$ & $\begin{array}{c}\text { All centers } \\
\mathbf{n}=\mathbf{7 4 0}\end{array}$ \\
\hline Alcohol & $48.3^{\mathrm{a}}$ & $67.5^{\mathrm{b}}$ & $70.3^{\mathrm{b}}$ & $56.6^{\mathrm{ab}}$ & $58.0^{\mathrm{ab}}$ & 0.001 & 60.2 \\
Marijuana & $32.2^{\mathrm{a}}$ & $27.2^{\mathrm{ab}}$ & $16.6^{\mathrm{b}}$ & $29.6^{\mathrm{ab}}$ & $23.3^{\mathrm{ab}}$ & 0.024 & 25.8 \\
Cocaine & $32.2^{\mathrm{a}}$ & $58.9^{\mathrm{b}}$ & $29.7^{\mathrm{a}}$ & $40.8^{\mathrm{a}}$ & $31.3^{\mathrm{a}}$ & $<0.001$ & 38.7 \\
Crack & $35.7^{\mathrm{a}}$ & $8.6^{\mathrm{b}}$ & $24.1^{\mathrm{a}}$ & $25.7^{\mathrm{a}}$ & $37.3^{\mathrm{a}}$ & $<0.001$ & 26.2 \\
Stimulants, sedatives & 2.8 & $3.3^{3}$ & 6.9 & 2.6 & 6.0 & 0.233 & 4.3 \\
Other drugs & $18.9^{\mathrm{ac}}$ & $45.7^{\mathrm{b}}$ & $12.4^{\mathrm{a}}$ & $27.0^{\mathrm{c}}$ & $21.3^{\mathrm{ac}}$ & $<0.001$ & 25.2 \\
Anything & 2.1 & 2.6 & 0 & 2 & 0.7 & 0.299 & 1.5 \\
\hline
\end{tabular}

Results expressed as number of subjects (\%).

CETAD (BA) = Center for Drug Abuse Studies and Therapy (Bahia); PROJAD (RJ) = Research and Assistance Program in Drug Addiction (Rio de Janeiro); PROMUD $(\mathrm{SP})=$ Women's Drug Dependent Treatment Center (São Paulo); UDED (SP) = Drug Dependence Unit (São Paulo); CPAD (RS) = Center for Drug and Alcohol Research (Rio Grande do Sul).

Results followed by different letters indicate the presence of statistically significant differences.

\section{Discussion}

The present study assessed the profile of drug abuse treatment seekers selected at five research centers located in four Brazilian states. Based on the data collected, we believe that the main goal of our study was met, namely, to improve our knowledge of the characteristics of alcohol and drugs users seeking treatment at the Brazilian public health system, of the severity of problems related to drug abuse, and of the main drug motivating treatment seeking. Patients selected at the four Brazilian states were similar, suggesting that our sample was representative of the general population of treatment seekers in Brazil, although some distinguishing features will be addressed below. In addition, our findings highlight the complexities involved in substance abuse treatment, with several variables influencing treatment planning and patient management. Such a complex scenario includes both individual variables (e.g., the presence of comorbidities and addition severity) and also environmental factors (e.g., characteristics of the health care system, social/ family support, etc.).

As mentioned above and shown in Table 1, the samples selected at all participating centers were similar and heterogeneous in terms of demographic characteristics - even at PROMUD, a center that provides treatment mostly to female patients at an outpatient basis. A predominance of male patients has been reported in previous substance abuse studies and at specialized treatment facilities. Women, in turn, are known to more frequently seek help for the treatment of alcohol use and mental health problems, ${ }^{16}$ but the stigma that still surrounds addicted women often delays or hinders their decision to seek treatment. ${ }^{17}$ Also, the fact that women usually report worse social support than men could influence the severity of their substance use. ${ }^{18} \mathrm{~A}$ Brazilian study of female alcohol users treated at a specialized outpatient clinic showed that most of them presented severe dependence. ${ }^{19}$

The mean age of our sample is in line with the relevant literature, which shows that substance abusers tend to seek treatment later in life than individuals with other psychiatric disorders, probably as a result of a higher number of barriers to treatment initiation. ${ }^{7}$ In turn, the higher mean age observed in our patients when compared with samples of non-alcohol drug users may be explained by the high rates of alcohol use and abuse observed in our study, as problems alcohol-related problems tend to manifest later in life. ${ }^{20,21}$ Moreover, our results showed a tendency to lower alcohol consumption and increased marijuana consumption in the state of Bahia (CETAD) when compared with the other centers, which may also be associated with the younger sample recruited at that center.

We found a low rate of patients living with a partner, which probably reflects the difficulties of living with a drug addict. This finding was also more common among PROMUD patients, which is consistent with other Brazilian studies that suggest a low tolerance among males toward female drug-dependent partners. ${ }^{22}$ Conversely, there is also evidence that a family environment marked by neglect, abandonment, physical abuse and lack of dialogue is associated with initiation of drug use. ${ }^{23}$ Therefore, it is difficult to know whether the dysfunctional relationships commonly observed among drug users are caused by drug abuse per se or whether they are a consequence of dysfunctional family patterns.

As expected, patients recruited at CETAD, the only research center located in the state of Bahia, northeast Brazil, differed from the remainder of the sample with regard to ethnicity: CETAD patients were predominantly Afro-Brazilian, compared to a majority of Caucasians selected at the other regions. According to the Brazilian 
Institute of Geography and Statistics, about $78 \%$ of the population in Bahia is Afro-Brazilian. Again, this is an example of the typical variability faced by studies conducted in large countries such as Brazil and justifies the inclusion of data collection sites located in different regions in order to broaden the validity of the study. ${ }^{24}$ However, in spite of the ethnic differences observed across the centers involved, the severity of problems related to the use of drugs was very similar in the different regions assessed.

Overall, the sample showed high education levels when compared to the general Brazilian population. Education level has long been associated with social and economic status in Brazil. As a result of flaws in the Brazilian public health system, individuals with better financial conditions tend to better identify and find treatment facilities, which probably explains the higher education rates found in our sample. Also, although education is known to be higher among women in Brazil, our study found lower results at the PROMUD center, where mostly women are treated. This finding may be the result of specific characteristics of the patients treated at that center, but it underscores the importance of studying the characteristics of drug users and to investigate how this population differs from non-drug users. A study conducted in the United States showed an association between poor literacy and higher rates of depressive symptoms in an alcohol- and drug-dependent population. ${ }^{25}$ Our study did not confirm those findings, but the PROJAD center, located in Rio de Janeiro, interestingly showed the lowest education levels and also the highest rates of psychiatric symptoms.

Our sample also showed a higher rate of unemployment $(47.4 \%)$ when compared to data available for the general Brazilian population. Official data for 2008 reveal much lower unemployment rates in Brazil, as low as $9.8 \%$, which points to the severity of problems related to drug abuse, including poverty and a circular cause and effect relationship involving jobseeking and unemployment among drug/alcohol users. ${ }^{26}$

Previous studies have shown high severity scores in many areas of the ASI- 6 related to alcohol and drug use in individuals seeking specialized treatment. ${ }^{27}$ Our sample showed a high prevalence of alcohol-related problems: $81 \%$ of the subjects had consumed alcohol in the 30 days preceding the interview (Table 2), and most reported alcohol abuse for about 5 years (Table 3). According to Caetano \& Laranjeira, several factors contribute to the high rates of alcohol use observed in Brazil, e.g., the expansion of local alcohol industries as a result of socioeconomic growth, massive advertising, low pricing and the lack of adequate consumption policies. ${ }^{28}$

A substantial percentage of the sample used marijuana in the 30 days preceding the interview (Table
2). The CETAD center showed the highest prevalence of marijuana use, which highlights the influence of cultural factures on the choice of drugs. Marijuana was introduced and distributed in Brazil through the Atlantic slave trade, which brought people from Africa in ships that reached mainly the state of Bahia, in the northeastern Brazilian coast. Some authors hypothesize that the high prevalence of marijuana use and abuse currently observed in the state of Bahia is still a legacy of that period. ${ }^{29}$ Similarly, the high rate of inhalant use obtained in the PROJAD sample may suggest either a sample selection bias or a local cultural specificity in Rio de Janeiro.

The high rate of binge drinking found in the PROJAD sample (Table 3 ) confirms a consumption pattern that had already been reported among Brazilian youths and adults. ${ }^{30,31}$ According to the National Institute on Alcohol Abuse and Alcoholism, the concept of binge drinking or "heavy episodic drinking" emerged based on evidence suggesting an increased risk of problems associated with the consumption pattern, and is defined as the consumption of five or more alcoholic drinks for men and four or more drinks for women on one occasion. One-fourth of alcohol users drink excessive quantities of alcohol and present binge drinking-related problems. $^{32}$ A Brazilian study conducted with 2,346 individuals aged 18 years or more showed that $28 \%$ regularly binge drank, and $25 \%$ reported at least one problem related to this behavior. ${ }^{33}$

In the last decade, an increase in cocaine consumption has been documented in Brazil, both in the general population and among students, as a result of an increasingly widespread use of crack. ${ }^{1,34-36}$ The barriers and difficulties faced by the Brazilian public health system to accommodate the needs of cocaine- and crack-dependent patients under treatment, especially as a result of the closure of psychiatric beds, are well known. ${ }^{37,38}$ However, the majority of studies conducted in other countries to analyze the characteristics of treatment seekers have focused predominantly on alcohol abusers or cocaine snorters. ${ }^{39,40}$ Therefore, there is a lack of studies assessing the characteristics of crack users and the role of crack as the drug motivating treatment seeking.

In our sample, crack use was one of the main reasons leading people to seek treatment. At the CPAD center, crack was the drug that motivated treatment seeking for almost half of the sample; in the remainder of the sample, crack use accounted for at least 30\% of the drugs motivating treatment seeking (Table 5). The typical crack user has been defined as a youth, unemployed, coming from a broken family, presenting with other psychiatric comorbidities and reporting 
concomitant use of other drugs. Crack use has been implicated in increased mortality rates among young people, especially as a result of crime and AIDS infection. ${ }^{41-44}$ Our results corroborate these findings: our PROJAD sample included the highest number of crack users and also presented the highest rate of legal problems (Table 4).

The results obtained for crack use in our sample underscore the current need to study the severity of problems related to the use of this particular drug. Crack was the second major drug motivating treatment seeking in our sample, a striking finding in view of the scarcity of information available on this drug in Brazil. Nevertheless, our results contribute to a better understanding of the profile of crack users and of their major concerns and reasons for seeking treatment, and therefore can be useful for the planning of therapeutic strategies.

The analysis of SS-Rs suggests that the differences observed across centers are the result of demographic and cultural factors that are inherent to studies conducted in large countries. In addition, none of the differences observed on SS-Rs reached statistical significance. Nevertheless, previous similar studies have used different versions of the ASI-6, which impeded the comparison of our data with the literature. Future studies are therefore needed to determinate whether or not our results can be generalized to other populations of drug users as well as to drug users not seeking treatment.

The severity of problems related to substance abuse is poorly understood in Brazil, but has been described in several studies conducted worldwide. U.S. studies have suggested a possible association between traumatic events in childhood and increased drug abuse severity, in addition to a greater vulnerability to relapse in this subgroup of patients. ${ }^{45,46}$ Another study conducted in India in 2003 showed that individuals seeking treatment for substance abuse, especially those presenting with psychiatric comorbidities, have a higher risk of contracting HIV. ${ }^{47}$ Similar findings have been reported in Brazil. ${ }^{48}$

Another important issue in this scenario is the possible relationship between substance abuserelated problems and the patients' reasons for seeking treatment. There is evidence that physical symptoms such as abstinence-related pain often motivate seeking treatment. ${ }^{18}$ A Canadian study has shown that, in a population of alcohol abusers, those with a diagnosis of dependence were more likely to seek treatment, suggesting an influence of severity of dependence on this outcome. ${ }^{39}$ However, most studies so far have been performed in populations with low rates of crack abuse when compared with Brazil. This difference may suggest that the pattern of drug consumption in general and of crack consumption in particular in Brazil may be different from (and significantly higher than) that in other countries. Finally, the increasing mortality rates associated with crack use in young populations further underscores the severity of the crack epidemic in Brazil. 49

In 2008, a sample of female patients seeking treatment for alcoholism was assessed for differences between early dropout and non-dropout patients. The study did not identify any social or demographic factor significantly associated with early dropout, but suggested an association of the latter with the pattern of alcohol consumption. ${ }^{50}$ Another study assessing a population of female drug users undergoing psychiatric treatment in São Paulo showed that representations on the use of alcohol in these women were linked to family, profession and gender issues, indicating that the search for treatment was not only motivated by substance use per se, but by all areas affected by such use. ${ }^{51}$

Our findings confirm previous evidence suggesting that the management of patients seeking drug abuse treatment should take several different aspects into consideration, e.g., education, employment, and family relationships, which often appear as areas of concern for these individuals; however, little information is available on the severity and impairment associated with drug use in these areas. ${ }^{52}$ Several treatment programs tend to focus on reducing drug use and ignore the psychosocial problems underlying the patient's decision to seek assistance. Initiatives that do not prioritize patient's needs commonly have higher rates of treatment noncompliance. ${ }^{5}$

Finally, another aspect that should be taken into consideration is that the specific characteristics of the health care services sought by drug users may also influence their decision to seek treatment. Such aspects may include political issues (e.g., the funding received by each service) and also characteristics of each individual treatment program (e.g., complex admission criteria, absence of appropriate services for groups such as women, waiting lists, and lack of cooperation across service organizations). ${ }^{7}$ Therefore, further studies should be carried out with the aim of providing a detailed profile of the health care services available for drug users in Brazil, with a focus on identifying variables that may influence specialized treatment seeking.

In sum, efforts should continue to be directed toward the identification and understanding of populations at greater risk for drug abuse, and to the continuou improvement of our knowledge of addictive behaviors in Brazil and in the world. Taken together, these data could be extremely useful for the development of cost- 
effective interventions aimed at increasing treatment seeking and treatment compliance rates, consequently decreasing relapse and reducing the social and financial costs involved in the treatment of substance abuse.

\section{References}

1. Carlini EA, Galduróz JC, Noto AR, Carlini CM, Oliveira LG, Nappo $\mathrm{SA}$, et al. II levantamento domiciliar sobre o uso de drogas psicotrópicas no Brasil: estudo envolvendo as 108 maiores cidades do país: 2005. São Paulo: Páginas \& Letras; 2007.

2. Bastos F, Bertoni N, Hacker M, Grupo de Estudos em População, Sexualidade e Aids. [Drug and alcohol use: main findings of a national survey, Brazil 2005]. Rev Saude Publica. 2008;42:10917.

3. Rehm J, Taylor B, Room R. Global burden of disease from alcohol, illicit drugs and tobacco. Drug Alcohol Rev. 2006;25:503-13.

4. Ciraulo DA, Piechniczek-Buczek J, Iscan EN. Outcome predictors in substance use disorders. Psychiatr Clin North Am. 2003;26:381409.

5. Otiashvili D, Djordjevic A, Morales D, Parsons A, Platt E, Stempliuk $\mathrm{V}$. Factors related to the process of seeking and completing treatment for drug abuse (qualitative methods in drug abuse research). Georgian Med News. 2005;(122):29-32.

6. Locastro JS, Potter JS, Donovan DM, Couper D, Pope KW. Characteristics of first-time alcohol treatment seekers: the COMBINE Study. J Stud Alcohol Drugs. 2008;69:885-95.

7. Rapp R, Xu J, Carr CA, Lane DT, Wang J, Carlson R. Treatment barriers identified by substance abusers assessed at a centralized intake unit. J Subst Abuse Treat. 2006;30:227-35.

8. McLellan AT, Alterman AI, Metzger DS, Grissom GR, Woody GE, Luborsky $L$, et al. Similarity of outcome predictors across opiate, cocaine, and alcohol treatments: role of treatment services. J Consult Clin Psychol. 1994;62:1141-58.

9. Silva $O$, Yonamine M. Drug abuse among workers in Brazilian regions. Rev Saude Publica. 2004;38:552-6.

10. Laranjeira R, Marques AC, Ramos Sde P, Campana A, Luz E Jr, França J. Who runs alcohol policy in Brazil? Addiction. 2007; 102:1502-3.

11. Marsden J, Gossop M, Stewart D, Rolfe A, Farrell M. Psychiatric symptoms among clients seeking treatment for drug dependence. Intake data from the National Treatment Outcome Research Study, Br J Psychiatry, 2000:176:285-9.

12. Borges CF, Baptista TW. [The mental health care model in Brazil: a history of policy development from 1990 to 2004]. Cad Saude Publica. 2008;24:456-68.

13. Moraes M. [Integral healthcare model for treating problems caused by alcohol and other drugs: perceptions of users, their companions and practitioners]. Cien Saude Colet. 2008;13:121-33.

14. Kessler $F$, Cacciola J, Faller $S$, Souza-Formigoni ML, Cruz M, Brasiliano S, et al. Adaptação transcultural multicêntrica da sexta versão da Escala de Gravidade de Dependência (ASI6) para o Brasil. Rev Psiquiatr Rio Gd Sul. 2007;29:335-6.

15. Henrique IF, De Micheli D, Lacerda RB, Lacerda LA, Formigoni ML. [Validation of the Brazilian version of Alcohol, Smoking and Substance Involvement Screening Test (ASSIST)]. Rev Assoc Med Bras. 2004;50:199-206.

16. Green CA, Polen MR, Dickinson DM, Lynch FL, Bennett MD. Gender differences in predictors of initiation, retention, and completion in an $\mathrm{HMO}$-based substance abuse treatment program. J Subst Abuse Treat. 2002;23:285-95.

17. Wechsberg WM, Luseno W, Ellerson RM. Reaching women substance abusers in diverse settings: stigma and access to treatment 30 years later. Subst Use Misuse. 2008;43:1277-9.

18. Stein MD, Mulvey KP, Plough A, Samet JH. The functioning and well being of persons who seek treatment for drug and alcohol use. J Subst Abuse. 1998;10:75-84.

19. Elbreder MF, Laranjeira R, Siqueira MM, Barbosa DA. Perfil de mulheres usuárias de álcool em ambulatório especializado em dependência química. J Bras Psiquiatr. 2008;57:9-15.

20. Hingson RW, Heeren T, Winter MR. Age at drinking onset and alcohol dependence: age at onset, duration, and severity. Arch Pediatr Adolesc Med. 2006;160:739-46.

21. Chen $\mathrm{CY}$, Storr CL, Anthony JC. Early-onset drug use and risk for drug dependence problems. Addict Behav. 2009;34:319-22.
22. Zilberman ML, Hochgraf PB, Brasiliano S, Milharcic SI. Drugdependent women: demographic and clinical characteristics in a Brazilian sample. Subst Use Misuse. 2001;36:1111-27.

23. Bernardy CC, de Oliveira ML. [The role of family relationships in the initiation of street drug abuse by institutionalized youths]. Rev Esc Enferm USP. 2010;44:11-7.

24. Brasil, Instituto Brasileiro de Geografia e Estatística (IBGE) . Censo Demográfico 2000 [Internet]. Rio de Janeiro: IBGE; 2002. [cited 2014 Nov 10]. http://www.ibge.gov.br/home/estatistica/ populacao/default_censo_2000.shtm

25. Lincoln A, Paasche-Orlow MK, Cheng DM, Lloyd-Travaglini C, Caruso C, Saitz R, et al. Impact of health literacy on depressive symptoms and mental health-related: quality of life among adults with addiction. J Gen Intern Med. 2006;21:818-22.

26. Santos GPG. Unemployment, informality and precariousness: the labor market situation in Brazil after 1990. Pro-Prosições. 2008;19:151-61.

27. McLellan AT, Cacciola JC, Alterman AI, Rikoon SH, Carise D. The Addiction Severity Index at 25: origins, contributions and transitions. Am J Addict. 2006;15:113-24.

28. Caetano R, Laranjeira R. A 'perfect storm' in developing countries: economic growth and the alcohol industry. Addiction. 2006;101:149-52

29. Fraga PCP. Plantios ilícitos no Brasil: notas sobre a violência e o cultivo de cannabis no polígono da maconha. Cad Ciencias Humanas - Especiaria. 2006;9:95-118.

30. Peuker AC, Fogaça J, Bizarro L. Expectativas e beber problemático entre universitários. Psic: Teor Pesq. 2006;22:193-200.

31. Silveira CM, Wang YP, Andrade AG, Andrade LH. Heavy episodic drinking in the Sao Paulo epidemiologic catchment area study in Brazil: gender and sociodemographic correlates. J Stud Alcohol Drugs. 2007;68:18-27.

32. Wechsler $H$, Nelson TF. Binge drinking and the American college student: what's five drinks? Psychol Addict Behav. 2001;15:287-91.

33. Laranjeira R, Pinsky I, Zaleski M, Caetano R. I Levantamento Nacional sobre os padrões de consumo de álcool na população brasileira. Unidade de Pesquisa em Álcool e Drogas, Departamento de Psiquiatria da Universidade Federal de São Paulo (UNIAD), e Secretaria Nacional Antidrogas, Presidência da República, Gabinete de Segurança Nacional (SENAD). 2007. [cited 2014 Nov 10]. http://bvsms.saude.gov.br/bvs/publicacoes/relatorio_ padroes_consumo_alcool.pdf

34. Galduróz JC, Noto AR, Nappo SA, Carlini EA. Household survey on drug abuse in Brazil: study involving the 107 major cities of the country--2001. Addict Behav. 2005;30:545-56.

35. Ferri CP, Laranjeira RR, da Silveira DA, Dunn J, FormigonI $\mathrm{ML}$. [Increase in the search for treatment by crack users in 2 outpatient clinics at the city of Sao Paulo from 1990 to 1993]. Rev Assoc Med Bras. 1997;43:25-8.

36. Inciardi JA, Surratt $H L$, Pechansky F, Kessler F, von Diemen $L$, da Silva EM, et al. Changing patterns of cocaine use and hiv risks in the south of Brazil. J Psychoactive Drugs. 2006;38:305-10.

37. Kessler F, Pechansky F. A contemporary psychiatric view on the crack phenomenon. Rev Psiquiatr Rio Gd Sul. 2008;30:1-3.

38. Kessler F, Woody G, De Boni R, Von Diemen L, Benzano D, Faller $S$, et al. Evaluation of psychiatric symptoms in cocaine users in the Brazilian public health system: need for data and structure. Public Health. 2008;122:1349-55.

39. Cunningham JA, Breslin FC. Only one in three people with alcohol abuse or dependence ever seek treatment. Addict Behav. 2004;29:221-3.

40. Evren C, Dalbudak E, Cakmak D. Personality dimensions in male patients with early-onset alcohol dependence who seek treatment. Isr J Psychiatry Relat Sci. 2009;46:204-6.

41. Ribeiro M, Dunn J, Sesso R, Dias AC, Laranjeira R. Causes of death among crack cocaine users. Rev Bras Psiquiatr. 2006;28:196-202.

42. Duailibi LB, Ribeiro M, Laranjeira R. Profile of cocaine and crack users in Brazil. Cad Saude Publica. 2008;24:s545-57.

43. Carvalho HB, Seibel SD. Crack cocaine use and its relationship with violence and HIV. Clinics (Sao Paulo). 2009;64:857-66.

44. Guimarães CF, Santos DVV, Freitas RC, Araujo RB. Perfil do usuário de crack e fatores relacionados à criminalidade em unidade de internação para desintoxicação no Hospital Psiquiátrico São Pedro de Porto Alegre (RS). Rev Psiquiatr Rio Gd Sul. 2008;30:101-8.

45. Schumacher JA, Coffey SF, Stasiewicz PR. Symptom severity, alcohol craving, and age of trauma onset in childhood and adolescent trauma survivors with comorbid alcohol dependence and posttraumatic stress disorder. Am J Addict. 2006;15:422-5.

46. Clark HW, Masson CL, Delucchi KL, Hall SM, Sees KL. Violent traumatic events and drug abuse severity. J Subst Abuse Treat. 2001;20:121-7. 
47. Carey MP, Chandra PS, Carey KB, Neal DJ. Predictors of HIV risk among men seeking treatment for substance abuse in India. Arch Sex Behav. 2003;32:339-49.

48. Wainberg ML, McKinnon K, Elkington KS, Mattos PE, Gruber Mann C, De Souza Pinto D, et al. HIV risk behaviors among outpatients with severe mental illness in Rio de Janeiro, Brazil. World Psychiatry. 2008;7:166-72.

49. Carvalho HB, Seibel SD. Crack cocaine use and its relationship with violence and HIV Clinics (Sao Paulo). 2009:64:857-66.

50. Elbreder MF, Laranjeira R, Siqueira MM, Barbosa DA. Perfil de mulheres usuárias de álcool em ambulatório especializado em dependência química. J Bras Psiquiatr. 2008;57:9-15.

51. Campos EA, Reis JG. Representações sobre o uso de álcool por mulheres em tratamento em um centro de referência da cidade de São Paulo - Brasil. Interface (Botucatu) [online]. 2010;14:539-50.
52. Figlie NB, Laranjeira R. Gerenciamento de caso aplicado ao tratamento da dependência do álcool. Rev Bras Psiquiatr. 2004;26:63-7.

\section{Correspondence:}

Sibele Faller

Center for Drug and Alcohol Research

Universidade Federal do Rio Grande do Sul

Rua Professor Álvaro Alvim, 400

90420-020 - Porto Alegre, RS - Brazil

E-mail: sifaller@gmail.com 